\title{
Energy and Lysine for Broilers from 44 to 55 Days of Age
}

- Author(s)
Araújo $\mathrm{LF}^{1}$
Junqueira $\mathrm{OM}^{2}$
Araújo CSS
Barbosa LCGS
Ortolan JH${ }^{1}$
Faria DE 1
Stringhini JH

1 Faculdade de Zootecnia e Engenharia de
Alimentos - FZEA/USP
2 Faculdade de Ciências Agrárias e
Veterinárias - FCAV/UNESP
3 Fundação de Ensino Superior Otávio Bastos
- UNIFEOB
4 Escola de Veterinária - EV/UFG

\section{Mail Address}

Lucio Francelino Araújo

Departamento de Zootecnia

Faculdade de Zootecnia e Engenharia de Alimentos

Av. Duque de Caxias Norte, 225

Jardim Elite - Caixa Postal 25

Universidade de São Paulo - FZEA/USP

13.635-900. Pirassununga, SP, Brazil

Phone: 551935654286

Fax: $\quad 551935654114$

E-mail: Ifaraujo@usp.br

\section{- Keywords}

Broilers, lysine, metabolizable energy, performance.

\section{ABSTRACT}

An experiment was conducted to evaluate the performance and carcass yield of broilers at 55 days of age fed diets with different levels of metabolizable energy and lysine. Evaluated data of performance were weight gain, feed intake, energy intake, lysine intake, caloric conversion and feed conversion. Carcass assessment was performed based on data from carcass yield, breast weight, whole wings, whole legs, back, head + neck, feet and abdominal fat. A $3 \times 3$ factorial arrangement was used, with 3 levels of metabolizable energy $(3,200 ; 3,400$ and 3,600 $\mathrm{kcal} \mathrm{ME} / \mathrm{kg}$ ) and 3 lysine levels $(0.95 \% ; 1.05 \%$ and $1.15 \%)$. There was no interaction between the two factors. Nevertheless, increasing levels of metabolizable energy improved weight gain $(745 \mathrm{~g} ; 841 \mathrm{~g}$ and $910 \mathrm{~g}$, respectively) and feed intake was higher in broilers receiving the diets with 3,200 and 3,600 kcal ME/kg. Overall performance was not affected by lysine levels. Feed conversion values were 2.69, 2.42 and 2.14 for birds fed diets with 3,$200 ; 3,400$ and 3,600 kcal ME/kg, respectively. Carcass yield and breast weight increased with higher levels of energy and lysine in the diets.

\section{INTRODUCTION}

The poultry industry became a highly competitive activity in the animal protein market. In the last 20 years, daily weight gain increased from 20 to $40 \mathrm{~g}$ and market age reduced from 12 to 6 weeks. The fast genetic advances and the increasing interest in poultry products lead to greater concern with the composition and quality of bird carcasses, especially with the production of low-fat carcasses. Fraps (1943) was one of the first researchers that showed that carcass composition may be influenced by energy and protein levels in diets.

More profitable production systems and better carcass yield might be achieved by an adjustment of the dietary energy level. Such adjustment has required many studies due to the rapid progress of broiler chickens. Consequently, the influence of dietary energy on growth, feed conversion and carcass quality is of great importance (Mendes \& Cury, 1986).

Besides studies on the optimum level of metabolizable energy, it is also important to determine the level of total amino acids, particularly methionine+cystine and lysine (Mendes et al., 1996), since carcass yield is a trait influenced by the energy-protein balance in the diet (Fischer, 1994).

Commercial sources of synthetic lysine and methionine are currently available. These are added to the diets so that the bird requirements of the first essential amino acids are fulfilled. Higher levels of protein or even lysine in isoenergetic diets increase protein retention and decrease carcass fat (Sibbald \& Wolynetz, 1986). 
In studies focused on the commercialization of parts of different broiler strains, breast meat production is one of the major goals and lysine is the most important nutrient to be studied (Moran, 1992). During the finishing phase, the body weight increases approximately $20 \%$ and broiler chickens consume more than $25 \%$ of the total feed intake for the entire rearing period (Skinner et al., 1992). Adverse effects in performance and carcass yield are perfectly possible in this period due to lysine limitation, since its contents in meat are exceptionally high. Besides, breast meat represents around 30\% of total broiler meat and 50\% of total edible protein (Summers et al., 1988).

The objective of this work was to study the productive performance and carcass traits of broiler chickens fed different levels of energy and lysine in the diet.

\section{MATERIAL \& METHODS}

A north-south oriented poultry house with blue curtains and clay-tile roof was used, with no ridge vent. There were 40 pens measuring $2.10 \mathrm{~m} \times 2.50 \mathrm{~m}$ each and separated by $0.40-\mathrm{m}$ walls and wire mesh.

One-day old male broiler chicks were submitted to three rearing phases: initial ( 1 to 21 days), growth (22 to 42 days) and finishing (43 to 54 days). The latter comprised the experimental period. Male broilers $(n=1,620)$ were randomly assigned to 9 treatments in a $3 \times 3$ factorial arrangement, considering the factors energy $\left(3,200 ; 3,400\right.$ and 3,600 kcal ME. $\left.\mathrm{kg}^{-1}\right)$ and lysine $(0.95 ; 1.05$ and $1.15 \%)$, in four replicates and 45 birds per replicate.

Corn-soybean diets were used (Table 1) and nutrient levels were in accordance to the recommendations of National Research Council (1994), except for energy and lysine.

Bird performance was analyzed based on body weight and weight gain, feed intake, caloric conversion, feed conversion, energy intake and lysine intake. Carcass yield and the percentage of some parts were evaluated from 10 birds randomly taken from each parcel at 55 days of age, in a total of 40 birds per treatment. Carcass yield was evaluated just after the slaughter and expressed as a percentage of individual live weight, as well as yields of breast, legs, wings, back, head+neck and feet.

\section{RESULTS AND DISCUSSION}

Performance results during the experimental period are shown in Table 2. Weight gain was directly proportional to the energy level of the ration, and there were statistically significant differences $(p<0.05)$. Feed conversion differences and some trends were similar to the data of weight gain, i.e., in the period from 44 to 55 days of age, feed conversion improved $(p<0.05)$ with the increase in the dietary energy level. Caloric conversion data during this period improved with higher energy levels in the diet.

It is interesting to note that feed intake was not inversely proportional to the energy level of the diet, as opposed to Hill \& Dansky $(1950,1954)$. Therefore, birds that were fed 3,400 kcal and 3,600 kcal ME. kg-1 had higher $(p<0.05)$ energy intake when compared to those receiving 3,200 kcal ME. $\mathrm{kg}^{-1}$.

According to Matterson et al. (1955) and Donaldson et al. (1956), birds will reduce feed intake proportionally after the energy requirements have been achieved. In this experiment it may be inferred that energy requirements in broilers older than 44 weeks of age may be higher than $3,200 \mathrm{kcal} \mathrm{ME} \mathrm{kg}^{-1}$, since a decrease in feed intake was not seen when diets with 3,400 and 3,600 ME. $\mathrm{kg}^{-1}$ were administered.

There was an increasing trend in feed intake from 44 to 55 weeks in the energy levels up to $3,400 \mathrm{kcal}$ ME. $\mathrm{kg}^{-1}$. Nevertheless, a decrease occurred when the birds received the higher energy level. These results showed that the birds fed with the ration with intermediate energy levels fulfilled their requirements.

Summers \& Leeson (1984) worked with increasing dietary energy levels up to $3,300 \mathrm{kcal} \mathrm{ME} \cdot \mathrm{kg}^{-1}$ and reported that birds receiving low-energy diets showed lower body weight, although they were more efficient in transforming energy into weight. Leeson et al. (1996) fed broilers in the finishing period with 2,700, 2,900, 3,100 and 3,300 kcal ME. kg-1 and found a decrease in feed intake and an improvement in feed conversion with increasing energy levels. It was also reported that broiler chickens show good ability to control their feed intake according to the energy level of the diet and birds with lower intake tend to deposit less fat in the carcass (Leeson et al., 1996). Broiler chickens fed increasing energy levels (from 2,600 to $3,200 \mathrm{kcal} \mathrm{ME}^{\mathrm{kg}}{ }^{-1}$ ) showed no significant effects on performance parameters, although there was a decrease in feed intake and an improvement in feed conversion with increasing dietary levels (Waldroup et al., 1990). It is worth noting that these experiments did not evaluate levels as high as those reported herein.

On the other hand, Holsheimer \& Veerkamp (1992) reported results $4.2 \%$ higher in weight gain and $12.1 \%$ 


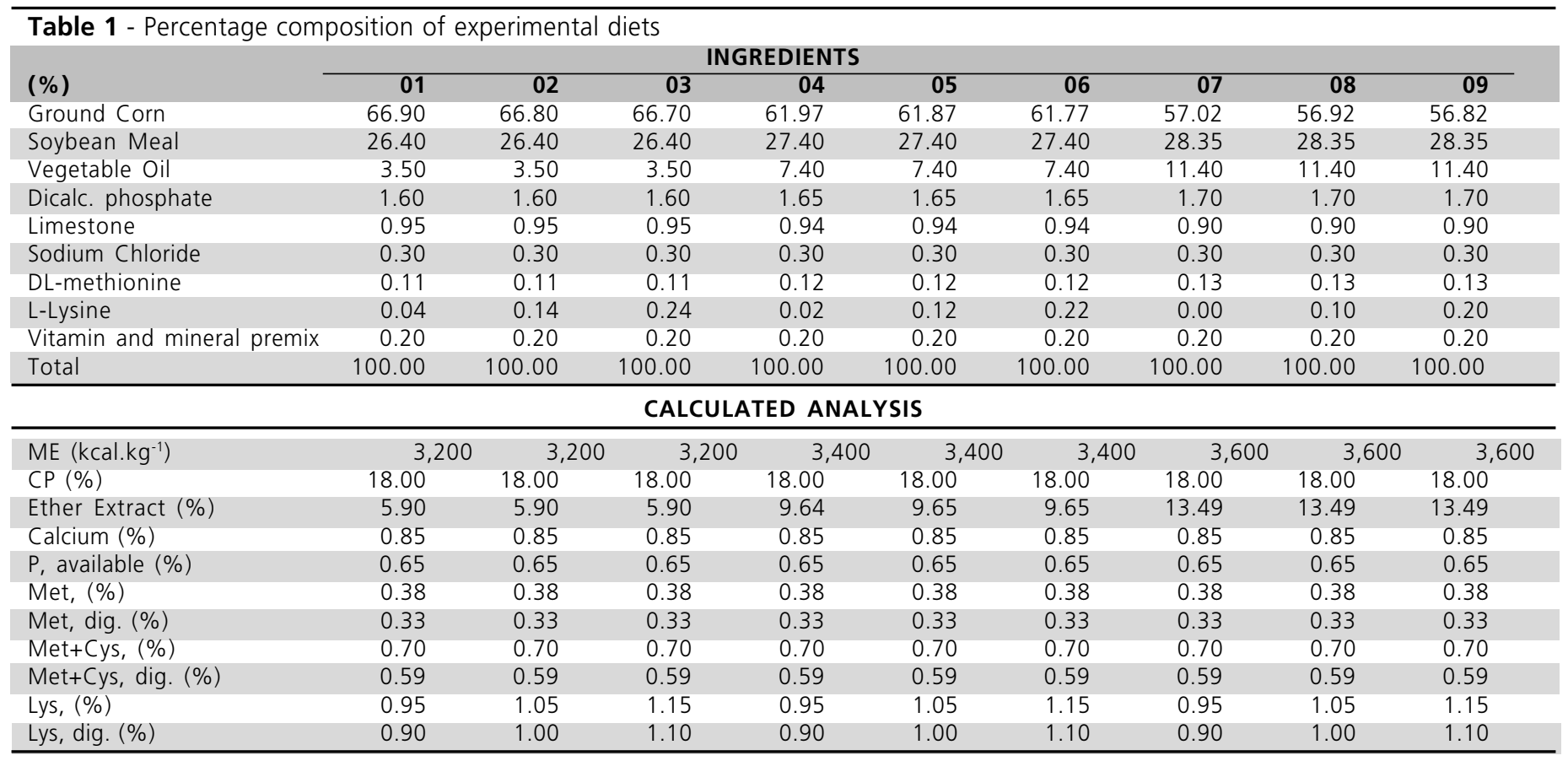

*Supplied (per kg): 2,500,000 IU vitamin A; 700,000 IU Vit. $D_{3} ; 7,000$ IU Vit. E; 700 mg Vit. K; 2,500 mg Vit B; 6,000 mcg Vit B $; 2 ; 26,000$ mg Niacin; 9,000 mg Pantothenic Acid; $200 \mathrm{mg} \mathrm{Se} ; 20 \mathrm{~g}$ antioxidant, 150,000 mg Mn; 100,000 mg Zn; 100,000 mg Fe, 16,000 mg Cu, 1,500 mg I.

Table 2 - Mean initial weight, mean final weight, weight gain, feed intake, caloric conversion, feed conversion, lysine intake, methionine intake, and methionine+cystine intake of birds fed different dietary levels of lysine and methionine+cystine from 44 to 55 days of age.

\begin{tabular}{|c|c|c|c|c|c|c|c|}
\hline \multirow[b]{2}{*}{ Parameter } & \multicolumn{3}{|c|}{ Energy (kcal ME. gg $^{-1}$ ) } & \multicolumn{3}{|c|}{ Lysine } & \multirow{2}{*}{$\begin{array}{l}\text { CV } \\
\text { (\%) }\end{array}$} \\
\hline & 3,200 & 3,400 & 3,600 & 0.95 & 1.05 & 1.15 & \\
\hline Mean initial weight (g) & $2,027^{A}$ & $2,005^{\mathrm{A}}$ & $2,043^{A}$ & $2,037^{a}$ & $2,023^{\mathrm{a}}$ & $2,015^{\mathrm{a}}$ & 1.68 \\
\hline Mean final weight $(\mathrm{g})$ & $2,772^{c}$ & $2,846^{\mathrm{B}}$ & $2,953^{\mathrm{A}}$ & $2,862^{a}$ & $2,842^{a}$ & $2,866^{a}$ & 0.98 \\
\hline Weight gain (g) & $745^{c}$ & $841^{B}$ & $910^{A}$ & $825^{a}$ & $819^{a}$ & $851^{\mathrm{a}}$ & 6.04 \\
\hline Feed intake (g) & $2,005^{\mathrm{B}}$ & $2,092^{A}$ & $2,006^{B}$ & $2,067^{a}$ & $2,034^{a}$ & $2,001^{a}$ & 2.95 \\
\hline Caloric conversion (kcal.kg-1) & $8,628^{A}$ & $8.472^{A B}$ & $7,965^{B}$ & $8,545^{a}$ & $8,502^{\mathrm{a}}$ & $8,019^{a}$ & 5.85 \\
\hline Feed conversion & $2.69^{A}$ & $2.42^{B}$ & $2.14^{c}$ & $2.44^{\mathrm{a}}$ & $2.44^{\mathrm{a}}$ & $2.37^{\mathrm{a}}$ & 6.99 \\
\hline Lysine intake $(\mathrm{g})$ & $21.05^{\mathrm{A}}$ & $21.96^{A}$ & $21.06^{\mathrm{A}}$ & $19.64^{c}$ & $21.36^{b}$ & $23.01^{\mathrm{a}}$ & 6.53 \\
\hline Energy intake (kcal) & $6,415^{\mathrm{B}}$ & $7,112^{\mathrm{A}}$ & $7,222^{\mathrm{A}}$ & $7,029^{\mathrm{A}}$ & $6,917^{a}$ & $6,803^{a}$ & 3.00 \\
\hline
\end{tabular}

For each factor (energy or lysine levels), means followed by different letters in the same row are statistically different by Tukey's test $(p<0.05)$

higher in feed conversion with increasing levels of metabolizable energy. Performance parameters showed a linear increasing response when levels of $3,200,3,400$ and 3,600 kcal ME. $\mathrm{kg}^{-1}$ were used for broiler chickens during the finishing phase (Pesti et al., 1983).

There were no differences in the studied parameters in relation to lysine levels. Feed intake and energy intake consequently showed decreasing trends with increasing lysine levels in the diet. As a result from the decrease in feed intake, there was an improvement in feed conversion, although no significant differences were seen between treatments. The results showed that $0.95 \%$ lysine was the most adequate level for weight gain and feed conversion.

According to Han \& Baker (1991), the increase in lysine levels may decrease feed intake but not weight gain. This might explain why feed conversion responds to increasing levels of lysine after weight gain requirements are maximized.

Parr \& Summer (1991) did not report significant responses in performance parameters with lysine supplementation $10 \%$ above the normal requirements. Kidd et al. (1997) supplemented diets with $105 \%$ of the lysine levels recommended by Skinner et al. (1992) and obtained better feed conversion and weight gain.

Table 3 presents carcass yield results at the end of the experimental period. There was an improvement in carcass yield (1.1\% and $2.3 \%)$, leg percentage $(2.2 \%$ and $6.2 \%)$ and breast percentage $(4.2 \%$ and $7.6 \%)$ when metabolizable energy levels of 3400

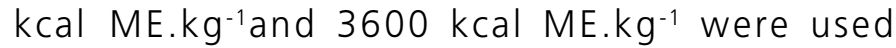

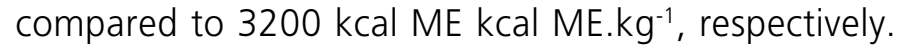
Back percentage decreased $3.7 \%$ with increasing 
Table 3 - Weight at slaughter, carcass yield, percentages of head, leg, wings, back, breast and feet, and abdominal fat in birds fed different dietary levels of lysine and methionine from 44 to 55 days of age.

\begin{tabular}{|c|c|c|c|c|c|c|c|}
\hline \multirow[b]{2}{*}{ Parameter } & \multicolumn{3}{|c|}{ Energy (kcal ME.kg-1) } & \multicolumn{3}{|c|}{ Lysine } & \multirow{2}{*}{$\begin{array}{l}\text { CV } \\
(\%)\end{array}$} \\
\hline & 3,200 & 3,400 & 3,600 & 0.95 & 1.05 & 1.15 & \\
\hline Slaughter weight (g) & $2,700^{C}$ & $2,775^{B}$ & $2,886^{A}$ & $2,793^{a}$ & $2,767^{a}$ & $2,800^{a}$ & 0.98 \\
\hline Carcass (\%) & $82.81^{C}$ & $83.71^{B}$ & $84.71^{\mathrm{A}}$ & $83.45^{a}$ & $83.61^{a}$ & $84.16^{a}$ & 0.84 \\
\hline Head (\%) & $6.01^{A}$ & $5.93^{A}$ & $6.10^{\mathrm{A}}$ & $5.99^{a}$ & $5.97^{a}$ & $6.09^{a}$ & 3.65 \\
\hline Feet $(\%)$ & $4.08^{\mathrm{A}}$ & $4.15^{\mathrm{A}}$ & $4.07^{A}$ & $4.09^{a}$ & $4.07^{a}$ & $4.14^{a}$ & 4.79 \\
\hline Wings (\%) & $8.80^{A}$ & $8.56^{\mathrm{A}}$ & $8.83^{\mathrm{A}}$ & $8.64^{a}$ & $8.73^{a}$ & $8.82^{a}$ & 5.47 \\
\hline $\operatorname{Back}(\%)$ & $16.16^{A}$ & $16.21^{A B}$ & $15.57^{B}$ & $15.73^{a}$ & $16.04^{a}$ & $16.16^{a}$ & 3.36 \\
\hline Breast (\%) & $23.44^{c}$ & $24.43^{B}$ & $25.21^{\mathrm{A}}$ & $24.16^{b}$ & $24.32^{a b}$ & $24.60^{a}$ & 1.43 \\
\hline Legs (\%) & $22.83^{B}$ & $23.32^{B}$ & $24.25^{A}$ & $23.22^{\mathrm{a}}$ & $23.47^{a}$ & $23.71^{\mathrm{a}}$ & 1.95 \\
\hline Abdominal Fat (\%) & $1.72^{\mathrm{A}}$ & $1.77^{\mathrm{A}}$ & $1.83^{\mathrm{A}}$ & $1.70^{a}$ & $1.79^{a}$ & $1.82^{\mathrm{a}}$ & 8.84 \\
\hline
\end{tabular}

For each factor, means followed by different letters in the same row are statistically different by Tukey's test $(p<0.05)$.

levels of energy, whereas no differences were seen in the percentages of wings, feet, and neck + head. These results are different from those reported by Deaton et al. (1997) and Holsheimer \& Veerkamp (1992), who found no increase in part yields when birds were fed increasing energy levels in the diet, although the percentage of abdominal fat increased. There were no significant differences in abdominal fat even though the dietary energy levels in ration increased.

Jackson et al. (1982) observed an increase in abdominal fat with increasing energy levels in the diet of birds, differently from the results found by Griffiths et al. (1977), who reported no increase in carcass fat.

Breast percentage was $0.6 \%$ and $1.8 \%$ higher $(p<0.05)$ when lysine levels increased to $1.05 \%$ and $1.15 \%$, respectively.

The other assessed parameters showed no significant differences due to the changes in lysine levels. Nevertheless, there was an improving trend in carcass yield and part percentages when lysine levels were increased.

Politi (1996) reported no significant effects on carcass yield with increasing levels of lysine in final diets for broilers. Nevertheless, other studies showed that higher lysine levels resulted in better carcass and part yields (Han \&Baker, 1991).

On the other hand, birds fed with deficient lysine levels showed reduction of $45 \%$ in the growth ratio and reductions of $65 \%$ and $40 \%$ in the weight of the muscles Pectoralis major and Sartorius, respectively, when compared to birds fed with normal lysine levels (Tesseraud et al., 1996). Besides, it was also reported higher protein lysis compared with protein synthesis.

Lower abdominal fat and higher breast and thigh yields were reported by Acar et al. (1991) and Holsheimer \& Veerkamp (1992) when increasing levels of lysine were used in diets.

According to Mabray \& Waldroup (1981), higher carcass fat may be explained by the following factors: higher energy:protein ratio in diets, amino acid imbalance, the type of fat used and dietary energy levels.

\section{CONCLUSION}

Weight at market age, carcass yield, breast and leg yields, weight gain, caloric conversion and feed conversion improved and back yield decreased with increasing levels of energy in the diet.

The increase in lysine levels was effective in increasing breast yield.

Bird requirements were fulfilled when $0.95 \%$ lysine was added to the diet.

\section{REFERENCES}

Acar N, Moran ET, Bilgili SF. Live performance and carcass yield of male broilers from two commercial strain crosses receiving rations containing lysine below and above the established requirement between 6 and 8 weeks of age. Poultry Science 1990; 70:23152321.

Deaton JW, Mcnaughton JL, Lott BD. The effect of dietary energy level and broiler body weight on abdominal fat. Poultry Science 1983; 62:2394-2397.

Donaldson WE, Combs GF, Romoser GL. Studies of energy levels in poultry rations: I. The effect of calorie-protein ratio of ration on growth nutrient utilization and body composition of chicks. Poultry Science 1956; 35:1100-1105

Fischer $C$. Use of amino acids to improve carcass quality of broilers. Feed Mix 1994; 2:17-20.

Fraps, G. S. Relation of the protein, fat, and energy of the ration to the composition of chickens. Poultry Science 1943; 22:421-424.

Griffiths L, Leeson S., Summers JD. Influence of energy system and level of various fat sources on performance and carcass composition of broilers. Poultry Science 1977; 56:1018-1026. 
Han Y, Baker DH. Effects of sex, heat stress, body weight and genetic strains on the dietary lysine requirement of broiler chicks. Poultry Science 1991; 72:701-708.

Hill FW, Dansky LM. Studies on the protein requirements of chickens and its relation to dietary energy level. Poultry Science 1950; 29:763.

Hill FW, Dansky LM. Studies of the energy requirements of chickens: I. The effect of dietary level on growth and feed consumption. Poultry Science 1954; 33:112-119.

Holsheimer JP, Veerkamp CH. Effect of dietary energy, protein, and lysine content on performance and yields of two strains of male broiler chicks. Poultry Science 1992; 71:872-879.

Jackson S, Summers JD, Leeson S. Effect of dietary protein and energy on broiler carcass composition and efficiency of nutrient utilization. Poultry Science 1982; 61:2224-2231.

Kidd MT, Kerr BJ, Anthony NB. Dietary interactions between lysine and threonine in broilers. Poultry Science 1997; 76:608-614.

Leeson S, Caston L, and Summers JD. Broiler response to energy or energy and protein dilution in the finisher diet. Poultry Science 1996; 75:522-528.

Mabray CJ, Waldroup PW. The influence of dietary energy and amino acid levels on abdominal fat pad development of the broiler chicken. Poultry Science 1981; 60:151-159.

Matterson LD, Potter LM, Stinson LD. 1955. Studies on the effect of varying protein and energy levels in poultry rations on growth and feed efficiency. Poultry Science 1955; 34:1210 (Abstract).

Mendes AA, Cury, PR. Effects of dietary energy levels and sex on broiler performance and carcass traits. In: Proceedings European Poultry Conference; 1986; Paris, France. p.543-547.

Mendes AA, Watkins SE, England JA. Influence of arginine:lysine ratios on performance of broilers during heat stress and cold stress. Poultry Science 1996; 75:472-481.

Moran ET. Nutrição e sua relação com a qualidade de carcaça de frangos de corte. In: Conferência Apinco de Ciência e Tecnologia Avícola; 1996; Santos, SP, Brasil. p.37-44.

National Research Council. Nutrient requirements of domestic animals: nutrient requirements of poultry. $9^{\text {th }}$ ed. Washington: National Academy Sciences; 1994.

Parr JF, Summer JD. The effect of minimizing amino acid excesses in broiler diets. Poultry Science 1991; 70:1540-1549.

Pesti GM, Whiting TS, Jensen LS. The effect of crumbling on the relationship between dietary density and chicken growth, feed efficiency, and abdominal fat pad weights. Poultry Science 1983; 62:490-494.

Politi ES. Efeitos de níveis altos de lisina, durante o período final de criação, sobre o desempenho e rendimento de carcaça de frangos de corte [dissertação]. Botucatu: FMVZ, UNESP; 1996.
Sibbald JR, Wolynetz MS. Effects of dietary lysine and intake on energy utilization and tissue synthesis by broiler chicks. Poultry Science 1986; 65(1):98-105.

Skinner JT, Waldroupand AL, Waldroup PW. Effects of dietary amino acid level and duration of finisher period on performance and carcass content of broilers 49 days of age. Poultry Science 1992; 71:12071214

Summers JD, Leeson S. Influence of dietary protein and energy level on broiler performance and carcass composition. Nutrition Reproduction International 1984; 29:757-767.

Summers JD, Leeson S, Spratt D. Yield and composition of edible meat from male broilers as influenced by dietary protein level and amino acid supplementation. Canadian Journal of Animal Science $1988 ; 68: 241-248$

Tesseraud S, Maa N, Peresson R, Chagneau AM. Relative responses of protein turnover in three different skeletal muscles to dietary lysine deficiency in chicks. British Poultry Science 1996; 37:641650

Waldroup PW, Tidwell NM, Izat AL. The effects of energy and amino acid levels on performance and carcass quality of male and female broilers grown separately. Poultry Science 1990; 69:1513-1521. 